\title{
COMMUNICATIVE-PRAGMATIC POTENTIAL OF THE MEANS OF EXPRESSION OF FUTURAL MEANING IN PUBLICISTIC DISCOURSE OF THE FRENCH LANGUAGE
}

\author{
I. Kirkovs'ka \\ Associate Professor, Candidate of Philological Sciences, \\ Head of Roman Philology Department, \\ Oles Honchar Dnipro National University \\ inga.kirkovska@gmail.com \\ orcid.org/0000-0001-7239-8773
}

Introduction. Term "futurality" has been widely used in Ukrainian and Russian linguistic literature to denote the research process of future action in Germanic languages (Byk, 1995; Kapustin, 1990; Panfilov, 1977; Selivanova, 2011; Suhomlina, 2007). Whereas French deals mostly with the study of the future tense functioning peculiarities to denote such a phenomenon (Gak, 2000; Manakin, 2007; Nika, 2011; Referovskaya, 1983) together with the term "prospectiveness". Since the 80 s of the XXth century the interpretation of the category of futurality, suggested by the representatives of the communicative and integrative pragmatics (Bally, 1942; Darrault, 1976; Gosselin, 1996; Ivon, 1953; Lakoff, 1987; Liere, 2011; Mauger, 1968; Serianni, 1989; Sten, 1952; Valette, 2006) has widespread. Scholars, studying the category of futurality from this aspect, point to the fact that apart from its proper meaning - action/event intention in the future - futurality can denote the speaker's communicative intention, not always corresponding to its primary meaning. The analysis of the category of futurality communicative-pragmatic potentials provides with the realization of a number of mindsets in communicative acts: demand, order, request, wish, compliment, etc. Such interpretation sidelines the linguistic characteristics of the stated category and is more aimed at the analysis of the category of futurality (further CF) forms functioning in speaking with consideration to a certain context. This approach, though, does not correspond to anthropocentric tendencies of the contemporary Language Studies development, according to which the subject of speaking proper is more meaningful in the construction of the statement content.

The purpose of the article is to suggest the comprehensive analysis of $\mathrm{CF}$, including stylistic, lexico-grammatical and communicative contexts of its representation. The achieve the stated aim the following tasks should be solved: 1) to study the stylistic and communicative peculiarities of the publicistic type of discourse; 2) to research the discourse differences between publicistic and literary types of discourse; 3 ) to define the types of futural semantics in the French publicistic type of discourse and exploit their communicative potential.

Methods and methodology of investigation. The article under consideration applies comprehensive approach to CF research, resulting in integrative approach usage, namely holistic approach to the problem of the linguistic meaning of the category under discussion, interpretation procedure (to differentiate modus components and separate modal meanings), method of semantic generalization to study the tense forms usage. To discover the remote structure with futural meaning the discourse analysis operations have been used. As part of the study, it appeared to be necessary to use contextual and functional-stylistic analyses. It should be emphasized, that pragmatic approach to linguistic phenomena analysis, which takes into consideration all extralinguistic factors, differentiating one communicative act from another, all nuances of relations between the parties of communication, is regarded as the most comprehensive. Taking into account the sphere of language functioning and the aim of communication, the study of speaker's impact on the addressee through the act of the communication and his response stimulation takes on particular significance.

Results and discussion. CF components in conjunction with aspectual shades of action performance in future are characterized by high communicative potential. Semantic-pragmatic potential of utterance with futural semantics should be treated as a part of the general "potential of 


\section{Ukrainian sense. 2020. ISSN 2313-4437}

linguistic unit functioning" - the most important notion in the Theory of Functional Grammar (Bondarko, 1984; Bulygina, 1981; Gak, 1998; Kirillov \& Starchenko, 2001).

The notions of strategy and tactics of language communication, overall context of utterance and speaker's communicative aim producing, realized within a single communicative act, are the foundation of the communicative-pragmatic analysis of the types of discourse, implementing CF. But communicative-pragmatic effect realization in a certain type of discourse may involve the combination of semantic-stylistic and contextological analysis of the utterance.

The given CF linguistic realization research grounds on illustrative material within the French-language publicistic discourse, rather than the certain types of speech acts, which, in their turn, make its integral part. This approach seems reasonable, as the theory of speech acts, having produced a number of interesting ideas, is unable to adequately interpret colloquial speech or artistic language. Though, thanks to the functional aspect of this theory, its potential can be used to study the discourse structure. Some scholars agree that the theory of speech acts is the basis of the discursive analysis (Makarov \& Klejner, 2007; Ryabinskaya, 2002). To distinguish the communicative strategies of the types of discourse, containing $\mathrm{CF}$, the following aspects of $\mathrm{CF}$ analysis should be taken into consideration: the choice of the universal speech intention, segmentation of the components of sentence semantics, separation of extralinguistic layer of the given information from proper linguistic one, reconstruction of utterance communicative unity. Argumentation, evaluation, empathy, etc. can be regarded as separate components of the strategy. The notion of the type of discourse, which is the speaker saying a certain utterance in the situation of face-to-face communication with the listener, is crucial for the analysis of the mechanisms of language interaction. Therefore, it appears to be significant to investigate the pragmatic saturation of utterance and its components.

V. Burbelo claims, that from this perspective, discourse should be determined in terms of functional-notional unity, systemic organization of lingual and paralingual components, their fixation, inseperability from certain social practice. Moreover, discourse does not just reproduce the principles of social and political organization of community life in its various manifestations, but it simulates them, grounding on its lingual and paralingual possibilities. First of all, it deals with agreed position of society, community, group as for a certain object through its linguistic denotation (verbalization). Besides, the scholar emphasizes the fact, that the procedure of denotation is connected with a definite aim - why and what for the denotation takes place and with a certain attitude to the thing denoted. This is the way the "teleological semantization" takes place, in the course of which the sign is placed within a definite system of relations, relevant for the given surrounding (Burbelo, 2015: 107).

Publicistic discourse is regarded as a certain type of discourse, as a correlate of publicistic style. Ranking discourses according to the "communication style" grounds on processual-resultive perception of the style as a complex of "cognitive procedures of knowledge processing, which has a respective verbal realization. Being a certain technique of communicative acts organization, in accordance with the speaker's peculiar pragmatics, style becomes a phenomenon of functional order" (Prihodko, 2009). Although, the problem of the notions - "functional style" and "discourse" - correlation is far from being solved, scholars find it possible to speak of colloquial, official, literary style, etc. Style is the discourse factor, formed in a consistent manner, and discourse is "the home of verbal means of realization of socially significant ideas, mirroring in cultural consciousness" (Prihodko, 2009).

From the perspective, peculiar for every communicative situation, any functional style is regarded as a certain set of stylistic characteristics, devices and dominants, which are the most adequate for discourse. In this sense functional style is "distinctive angle of discourse world model development" (Prihodko, 2009). Nevertheless, according to O. Honchar (2010), if we take this concept as a fundamental one for our investigation, we should also take into account the fact that this correlation of the notions - "discourse" and "style" - seems to be sketchy due to the fact that they belong to different scientific paradigms and, accordingly, have different spheres of usage (discourse is the subject of disciplinary study, while functional style remains within linguistics and 


\section{Ukrainian sense. 2020. ISSN 2313-4437}

Literature Studies). As for the interpretation of publicistic genre as a certain style of written speech, used in Mass Media, it is treated as "a kind of intermediary sphere of artistic, business and scientific communication" (Matiukha \& Karpinska, 2016: 273).

Speaking about time in publicistic writing, G. Solganik (2000) points out to the fact that it is different from time in belle-letters - it is real, recent, mostly the same as historical time in publicistic writing, thus intensifying such an important feature of publicistic writing as documentation. The scholar makes a point that research of time in publicistic writing has only started. Comparison of time structure of different types of texts - literary, publicistic and scientific - demonstrates distinction between them in temporal structure. There is a number of definitions of genre, and none of them can be taken as universal - the one that can be applied to all the categories of publicistic texts. The only thing all scholars agree on - it is the constancy and frequency of occurrence of any given type of texts in time and in different types of newspaper, magazine or journal issues, TV and radio programmes. In the most general aspect genre can be defined as "certain unity of notional and formal characteristics" (Konikov, 1071: 370).

The main reasons of genre classification of Mass Media are, firstly, variety of objects of reality, reflected by journalism, secondly, the main types of objects, thirdly, variety of certain real situations, characteristic of the objects of reality, fourthly, main types of situations, constituents of disciplinary branch and, finally, variety of subject-object characteristics of the reality reflected.

Contemporary science classifies genres in accordance with a number of characteristics. First of all, according to the subject of perception and reflection of the object by the publicist. The second feature is the certain focus of the material. The third one is connected with the width of coverage of reality and the scale of summary and statements. According to these characteristics all the publicistic materials can be divided into three major class descriptive groups. Their functional dominant also varies depending on the type of texts. Within press publicism three types of texts have been distinguished: informative, analytical and feature-publicist.

Information value, persuasive power, accuracy, appeal, universal access, logic nature, actuality, predictive value, validity have been named among the major characteristics, uniting these types of texts. Usage of the CF forms in the publicistic style is predetermined by the speaker's will to persuade the reader as soon as possible that things described will soon take place, make them believe that certain ideas are right with the help of cause-and-effect links. Let us pay attention to the peculiarities of $\mathrm{CF}$ forms usage in the analytical article:

Dans l'ère qui s'ouvre, le Japon devra certainement compter avec le formidable expansionnisme chinois, le désengagement américain, et, qui sait, les missiles nord-coréens autant de menaces qui favorisent les projets nationalistes de l'actuel gouvernement (Japon: les défis de l'ère Reiwa).

In the extract under consideration the author realizes their own view of the situation by using the modal devoir in Futur simple, thus introducing the modal shade of uncertainty and probability of action in the future. Such layer of two modal means at the same time covers the semantics of explicit subjectivity of the author bordering with the situation evaluation in the future. The statement contains implicit modus category of persuasiveness, backed by the previous world practice. So, on the one hand, the author persuades, and on the other, - they appeal to the precedence of the event, thus adding to their own elite language peculiarity. Similar semantic effect can be found in the following example, the way verb falloir has been used:

Aujourd'hui, quelque 8 milliards d'euros par an y sont affectés au niveau mondial. Les experts estiment qu'il en faudrait entre 200 et 300 milliards chaque année (Biodiversité: 1'humanité face à ses responsabilités).

By conveying the aspectual situation of need-necessity, verb falloir, used in Conditionnel, gains the meaning of predictive future and is similar to semantics falloir + Futur simple. The given extract creates the atmosphere of the close adherence (time - aujourd'hui, deictic - les export estiment) to the certain situation "here and now". Here the author covers the world elements for himself/herself and the others, he/she positions himself/herself as a man of experience and works 
out the precentral model of reality description. The author applies the perceptive-descriptive structures.

The analysis of the factual material proves that predictive publicism makes not an insignificant part of CF rate of usage. The notion "prediction" (Greek. $\left.\pi \rho \gamma_{\gamma} v \sigma \sigma 1 \zeta\right)$ means forecast, prognosis. But in the scientific meaning prediction is not only the future forecast. Scientifically, prediction means the statement of probability with a certain level of possibility concerning the unknown or nonidentified facts, grounding on the study and summary of the past experience and intuition in regards to the systems development in the future (Pliushch, 1986: 45). Predictions make a certain model of probability, which can be used to foresee the consequences and take actions aimed at the social result secure.

The investigation of analytical publicism demonstrates the realization of futural semantics with future-prediction meaning with the use of futural presence, for instance:

La planète s'achemine vers la sixième extinction de masse. Et celle-ci risque de se produire non plus à l'échelle des temps géologiques, mais en quelques décennies seulement. Avec un unique responsable: l'homme (Biodiversité: l'humanité face à ses responsabilités).

The present sentence actualizes futural semantics with the help of two factors - verbs semantics and Futural Presence in the meaning of nontemporal future. The description is a general, obligatory, dictatorial statement, combined with philosophical meditations of predictive nature. Verb s'acheminer standing for "move forward" semantically can be distinguished as the verb of motion, directing the action into future, and the verb risquer de means getting into a new situation or the situation on the point of taking place and verbalizes aspectual situation of inchoativeness. Contextual integration of these factors provides prediction with futural semantics. In this discourse area the semiotic reality learning in its emotional experience, in the attempt to harmonize with the world takes place. Precentrality is expressed through the world joining the personal symbolic space of the speaker. Precentrality consists in the world joining the personal symbolic space of the speaker and this construction projection from there to the addressee, namely through the subject - planète and the detached object - homme.

Future-prediction is widely used in analytical economic reviews, for instance:

L'institut de Francfort n'attend plus que 1,1\% de croissance en 2019 pour l'ensemble de la zone et $1,6 \%$ en 2020, contre 1,7\% pour les deux années lors de ses précédentes prévisions communiquées en décembre. Pour 2021, elle table toujours sur 1,5\%.

Le président de l'institution, Mario Draghi, admet ainsi implicitement que la BCE n'atteindra pas avant 2022 son objectif d'une hausse des prix légèrement inférieure à $2 \%$, et n'a donc pas encore remporté son pari (La BCE assombrit son pronostic économique en zone euro).

Verb attendre, used in the restrictive construction ne...plus que, obtains the meaning of the single action in the stated future with the shade of negative assessment. Semantics of verb tabler sur "be up to" emphasizes some result expectations, being the actualizer of conceptual situation "intention, planning". Verb atteindre, used in negative form of Futur simple reflects the analyst's idea about failure in the future. The precedent meaning of futural presence is intensified by statistic data, probably stated in the previous calculations and meaningful in the future.

The composite set up of the analytical article in combination with predictive comments of the author contains language markers, which actualize "zone of potential background", for instance:

L'année 2019 sera beaucoup plus difficile du point de vue de la stabilité et de la croissance économiques à l'échelle mondiale. Nous croyons que la "bulle" sur le marché américain explosera et que le monde fera face à une récession.

Discourse actor creates his/her individual, shaped reality by dispensing the syncretism of perceptual unity into specific facts in the future.

Et de conclure: "En cas de crise pareille, le monde actuel dominé par le dollar a toutes les chances de se désintégrer en plusieurs zones monétaires, si bien que l'Occident perdra la majorité des parts au sein de l'économie mondiale et que la Chine deviendra le nouveau leader international" (Une crise financière...). 


\section{Ukrainian sense. 2020. ISSN 2313-4437}

Together with verbs denoting possible dynamics, according to the author's point of view, l'année 2019 sera, le marché américain explosera, le monde fera, the "actual state of things" is introduced through direct speech - le dollar a toutes les chances de se désintégrer ... si bien que l'Occident perdra la majorité des parts, which plays the role of the argument to the preceding and following author's reflections l'Occident perdra la majorité... que la Chine deviendra le nouveau leader international. Conditionnel plays the role of objectivizer of "aspectual situation of the potential".

Experiencer, acting as persuasive witness, by dispensing the syncretism of perceptual unity of his/her own reflection of the situation under discussion into fragments, expressing them in the forms of future tense, runs them through the prism of various modalities and his/her own assessment. Future tense brings meaningfulness and communication significance to this fragment.

It should be pointed out that the record of the factual material demonstrates the cases of futural semantics representation in analytical articles by creating the futural context through combination of the state verbs (être + p.p. menacer) and verbs of intensive action (s'accélérer), for instance:

Un million d'espèces animales et végétales, terrestres ou marines - soit une sur huit - sont menacées de disparition. Et le rythme s'accélère dramatiquement (Biodiversité: l'humanité face à ses responsabilités).

Modal verb pouvoir, expressing potential possibility in the future in Présent, can create the same stylistic effect, for instance:

Chez le consommateur, la capacité d'analyse et de raisonnement peut parfois se substituer par des envies, intuitions, sentiments.

Incitant à boire de l'alcool, la publicité peut alors dévoiler des aspects négatifs et détient un côté dangereux car elle peut se révéler néfaste pour la santé. La publicité peut en effet inciter à consommer les "mauvais" produits (L'influence de la publicité sur les consommateurs).

One of the most widespread types of publicistic discourse, which conventionally expresses the futural semantics of "future-prediction", is the horoscope. According to the classification of V.Karasika, this type of discourse is regarded as ezoteric one (Karasik, 2002: 277).

Vous devrez donner la priorité aux projets ou à votre activité. Le labeur, les occupations diverses seront vos préoccupations premières durant une grande partie de l'année. L'ennui ne sera donc pas au rendez-vous.

Ce devrait être une période assez active. Vous n'aurez pas le loisir de vous tourner les pouces. Pour certaines, 2020 vous permettra de marquer des points importants dans votre travail. D'autres saisiront toutes les occasions pour améliorer leur cadre ou leurs conditions de vie.

Janvier sera parfait pour signer un contrat ou pour nouer des contacts clés pour votre avenir. En mars, passez à l'action et lancez des projets. En avril et en mai, dites oui à la nouveauté. En septembre, donnez libre cours à vos envies et à vos aspirations. Faites-vous plaisir.

Ce sera une année cruciale pour vos entreprises et votre activité. Vous aurez l'occasion de vous imposer dans votre domaine de compétences. Certaines verront même leur travail reconnu. Ce sera une excellente année pour montrer de quoi vous êtes capable, décrocher une promotion, gravir l'échelle sociale ou pour voir aboutir certains de vos projets. Vous terminerez 2020 heureuse et satisfaite.

Vous chercherez les solutions pour améliorer vos conditions de vie et vos revenus. Astucieuse et ambitieuse, vous saurez faire ce qu'il faut pour booster vos finances. Vous verrez donc votre budget augmenter au cours de l'année.

Vous vivrez de jolis moments sur le plan amical. La douceur, la bonne humeur, le partage et l'écoute vous accompagneront une grande partie de l'année, notamment d'avril à août.

En couple, vous aurez à cœur d'améliorer votre cadre de vie. Ainsi, vous serez très attachée à mieux vivre votre relation. D'un bout à l'autre de l'année, vous vous efforcerez d'être plus à l'écoute de votre moitié et vous privilégierez l'harmonie ainsi que la douceur. Célibataire, ce ne sera pas forcément la meilleure année pour vivre le grand amour. Qu'à cela ne tienne, vous saurez saisir toutes les occasions qui vous permettront de vous amuser et de flirter. 


\section{Ukrainian sense. 2020. ISSN 2313-4437}

Si vous pouvez compter sur un beau capital énergétique, vous ne passerez pas outre quelques moments de fatigue intense. Restez vigilante sur le premier et le dernier trimestre 2020 (Cosmopolitan).

The given text is an interesting combination of predictive future, expressed mostly by the forms of Futur simple (bold print) and adverbial modifiers of time (underlined in the text). The social authority of the author is recognised - astrologer, language personality on the high level of organized nature as for the outline of the eventrs and structuring of the text, the dynamics of the events predicted is rather high (more than 30 verbs have been used), the colouting of the text is romantic and playful, corresponding to the form of ezoteric forecast. All the communicative instrumentarium is aimed at modeling "better tomorrow" on the New Year's eve but not at informing the reader.

Another kind of futural semantics in the publicistic type of discourse is the volition of the author or their personal desires concerning some event in the future, for instance:

Il faudra alors prendre des engagements précis, déclinés en politiques publiques et associant l'ensemble des acteurs de l'économie et de la société civile (Biodiversité: l'humanité face à ses responsabilités).

The usage of impersonal construction il faut in Futur simple to denote "volitive future" should be regarded as a contextual phenomenon rather than a general tendency. Subjonctif and Impératif are the common means to convey the meaning of volition, which is natural, as these grammar means are the verbalizers of the corresponding mental spheres of volition and order, for instance:

Il faut qu'on m'explique... ! (Chronique d'abonnés).

Predictably, the notion of volitive future is used in the social cause advertisement and other types of advertising, but mainly in Impératif, for instance:

Maquillage permanent: ne risquez pas votre peau! (Maquillage permanent);

Laissez-vous flotter! Cinq idées pour dormir sur l'eau (Bostnavaron \& Sultan-R'bibo).

Conclusions. Publicistic type of discourse of the French language contains all four moods of French, able to realize two major forms of futural semantics - "future prediction" and "volitive future". Publicistic style, as well as literary style, is characteristic of futural contexts, containing integrative combinations of verbs of movement, semantics of the verbs, conveying different types of situations of aspect and grammar means. The main aim of Mass Media is not to reflect the author's mentality, but it is the desire to affect the narratee or reader. This aim predetermines the major strategies of publicistic discourse, using language and speech potential of CF means. As for communicative strategies, they are: the construction of the addressee's idea with the help of different forms (analytical articles, horoscopes, etc.); appeal to the category of precedence (statistic data, quotations, allusions, etc.); one's own elite language personality boost (author's status, proofs of their expert knowledge); usage of modus category of persuasiveness, oriented to the future. Publicistic discourse has a more flexible social role than the literarty discourse, as it is more focused on the possible needs of the society.

Publicistic discourse feeds into existential discourse basic model. Its essence is in semiotisation of the future reality in the long term or near-term perspective. Taking into consideration the bidirectional nature of the text, appealing both to the author and the reader, making the latter not "let us go through" the future together, which has been suggested by the author, as in literary discourse, but try to "make a model" of it or "spy on it" together. Communicative-pragmatic potential of the means of $\mathrm{CF}$ feeds into the cultural model of the future perception, typical for the French language, namely - "future prediction". Volitive future, conveyed by Impératif, is a separate modal meaning of CF in publicistic discourse. Prospects of the future investigations lie in the study of CF expression in different types of language acts such as: emotional-evaluative, declarative, directive, commissive, representative, in particular, wishes, permissions, demands, hints. Moreover, it seems highly potential to research CF in different types of discourse, namely, in esoteric, culinary, advertese, intensional, etc. 


\section{Ukrainian sense. 2020. ISSN 2313-4437}

\section{REFERENCES}

Bally, Ch. (1942). Syntaxe de la modalité explicité. Cahiers de F. De Saussure. Genève: Librairie Droz.

Bondarko, A. V. (1984). Funkcionalnaya grammatika [Functional grammar]. Leningrad: Nauka [in Russian].

Bulygina, T. V. (1981). O granicah i soderzhanii pragmatiki [On boundaries and content of grammar]. Izvestiya AN SSSR. Seriya literatury i yazyka - Literature and language series, 4, 24-36 [in Russian].

Burbelo, V. B. (2015). Pro modeliuvalni zasady dyskursu [On the modelling fundamentals of discourse]. Movni i kontseptualni kartyny svitu - Linguistic and concept worldviews, 1, 104-119 [in Ukrainian].

Byk, I. S. (1995). Katehoriia futuralnosti v suchasnii anhliiskii movi ta zasoby yii realizatsii [The category of futurality in modern English and ways of its realization]. Extended abstract of Candidate's thesis. Lviv [in Ukrainian].

Darrault, I. (1976). Présentation. Langage, 43, 3-9.

Gak, V. G. (1998). Yazykovye preobrazovaniya [Linguistic transformations]. Moscow: Yazyki russkoj kultury [in Russian].

Gak, V. G. (2000). Teoreticheskaya grammatika francuzskogo yazyka [Theoretical grammar of French]. Moscow: Dobrosvet [in Russian].

Gosselin, L. (1996). Sémantique de la temporalité en français. Romanistisches Jahrbuch, 48.

Honchar, O. S. (2010). Publitsystychnyi dyskurs ta yoho funktsii [Publicistic discourse and its functions]. Novitnia filolohiia - Modern philology, 16 (36), 31-33 [in Ukrainian]. $169-177$.

Ivon, H. (1953). Indicatif futur antérieur ou Suppositif probable? Le français moderne, 3,

Kapustin, M. (1990). Konec utopii? Proshloe i budushee socializma [The end of Utopia? The past and the future of socialism]. Moscow: Novosti (IAN) [in Russian].

Karasik, V. I. (2002). Yazyk socialnogo statusa: Sociolingvisticheskij aspekt. Pragmalingvisticheskij aspekt. Lingvosemanticheskij aspect [The language of social status: Sociolinguistic aspect. Pragmalinguistic aspect. Linguosemantic aspect]. Moscow: ITDGK "Gnozis" [in Russian].

Kirillov, V. I., \& Starchenko, A. A. (2001). Logika [Logics]. Moscow: Yurist [in Russian].

Konikov, I. A. (1971). Materializm Spinozy [Spinoza's materialism]. Moscow: Nauka [in Russian].

Lakoff, G. (1987). Women, fire and dangerous things. What categories Revel about the mind. Chicago, London: The University of Chicago press.

Liere, A. (2011). Entre lexique et grammaire: les périphrases verbales du Français. Linguistics. Université du Littoral Côte d'Oplac.

Makarov, V. L., \& Klejner, G. B. (2007). Mikroekonomika znanij [Microeconomics of knowledge]. Moscow: Ekonomika [in Russian].

Manakin, V. M. (2007). Do pitannya pro "semantichni primitivi” v suchasnij lingvistici [On the problem of "semantic primitives" in modern linguistics]. Aktualni problemi inozemnoyi filologiyi: lingvistika i literaturoznavstvo - Topical issues in the foreign philology: linguistics and literary studies, 1, 74-80 [in Ukrainian].

Matiukha, H. V., \& Karpinska, M. O. (2016). Funktsionalni styli suchasnoi movy ta osoblyvosti interpretatsii anhlomovnoho hazetnoho styliu. [Functional styles of modern language and the peculiarities of the English-language newspaper style interpretation]. Naukovyi visnyk Mizhnarodnoho humanitarnoho universytetu. Seriia: Filolohiia - Scientific Journal of the International Humanities University. Series : Philology, 24 (2), 126-128 [in Ukrainian].

Mauger, G. (1968). Grammaire pratique du français d'aujourd'hui. Paris: Librairie Hachette.

Nika, O. (2011). Teoriia modusu v suchasnii linhvistytsi [Modus theory in contemporary linguistics]. Ukrainska mova - Ukrainian, 2, 19-29 [in Ukrainian]. 


\section{Ukrainian sense. 2020. ISSN 2313-4437}

Panfilov, V. Z. (1977). Kategoriya modalnosti i ee rol v konstituirovanii predlozheniya i suzhdeniya [The category of modality and its role in the sentence and statement formation]. Voprosy yazykoznaniya - Issies of language studies, 4, $37-49$ [in Russian].

Pliushch, M. Ya. (1986). Katehorii subiekta i obiekta v strukturi prostoho rechennia [The category and subject and object in the simple sentence structure]. Kyiv: Vyshcha shkola [in Ukrainian].

Prihodko, A. N. (2009). Taksonomicheskie parametry diskursa [Taxonomic characteristics of discourse]. Yazyk. Tekst. Diskurs: Nauchnyj almanah Stavropolskogo otdeleniya RALK Language. Text. Discourse: Scientific Journal of Stavropol division of RALK, 7, 22-30 [in Russian].

Referovskaya, E. A. (1983). Lingvisticheskie issledovaniya struktury teksta [Linguistic studies of the text structure]. Leningrad: Nauka [in Russian].

Ryabinskaya, N. S. (2002). Rech kak socialnoe dejstvie: osnovnye ponyatiya diskursivnogo analiza [Speech as a social act: basic notions of the discourse analysis]. Sociologicheskij zhurnal Sociolinguistic Journal, 4, 78-91 [in Russian].

Selivanova, O. O. (2011). Linhvistychna entsyklopediia [Linguistic encyclopedia]. Poltava: Dovkillia-K [in Ukrainian].

Serianni, L. (1989). Grammatica italiana; italiano commune e lingua letteraria. Torino: Casa Editrice UTET.

Solhanyk, H. Ya. (2000). Pro novi aspekty vyvchennia movy ZMI [On the new aspects of the mass media language investigation]. Visnyk Moskovskoho universytetu. Zhurnalistyka Scientific Journal of the Moscow university. Journalism, 3, 33-34 [in Ukrainian].

Sten, H. (1952). Les temps du verbe fini (indicatif) en français moderne. Copenhague, E. Munksgaard.

Suhomlina, T. A. (2007). Kategoriya futuralnosti i sredstva ee yazykovoj manifestacii (na materiale anglijskogo yazyka) [The category of futurality and means of its language manifestation (in the English language)]. Extended abstract of Candidate's thesis. Samara [in Russian].

Valette, M. (2006). Linguistiques énonciatives et cognitives françaises. Gustave Guillaume, Bernard Pottier, Maurice Toussaint, Antoine Culioli. Paris: éd Champion.

Varshavskaya, A. I. (1984). Smyslovye otnosheniya v strukture yazyka [Sense relations within the language structure]. Leningrad: Izd-vo Leningradskogo Universiteta [in Russian].

\section{SOURCES}

Japon: les défis de l'ère Reiwa. Le Monde. 04 mai 2019. Retrieved from: https://www.lemonde.fr/idees/article/2019/05/04/japon-les-defis-de-l-erereiwa_5458235_3232.html

Biodiversité : l'humanité face à ses responsabilités. Le Monde. 06 mai 2019. Retrieved from: https://www.lemonde.fr/idees/article/2019/05/06/biodiversite-1-humanite-face-a-sesresponsabilites_5458837_3232.html

La BCE assombrit son pronostic économique en zone euro. Le point. 07/03/2019. Retrieved from: https://www.lepoint.fr/automobile/la-bce-assombrit-son-pronostic-economique-en-zone-euro07-03-2019-229 8972_646.php

Une crise financière de taille menacerait le monde en 2019. International. 12:16 05.01.2019. Retrieved from: https://fr.sputniknews.com/

L'influence de la publicité sur les consommateurs. L'équipe Dynamique Entrepreneuriale. 31.01.17. Retrieved from: http://www.dynamique-mag.com/article/l-influence-de-la-publicite-surles-consommateurs.5396

Cosmopolitan. Spécial fêtes. Retrieved from: https://www.cosmopolitan.fr/astro/horoscope/horoscope-de-l-annee/lion/

Chronique d'abonnés. Le Monde. 13.02.10. Retrieved from: https://www.lemonde.fr/idees/chronique/2010/02/14/il-faut-qu-on-m-explique__ 1305632 3232.html 


\section{Ukrainian sense. 2020. ISSN 2313-4437}

Maquillage permanent: ne risquez pas votre peau! RTS Radio Télévision Suisse. 15 septembre 2009. Retrieved from pages.rts.ch/emissions/abe/sante-cosmetique/829128-maquillagepermanent-ne-risquez-pas-votre-peau.html

Bostnavaron F., Sultan-R'biboY. Laissez-vous flotter! Cinq idées pour dormir sur l'eau. Le Monde. 05 mai 2019. Retrieved from: https://www.lemonde.fr/m-styles/article/2019/05/05/laissezvous-flotter-cinq-idees-pour-dormir-sur-1-eau_5458356_4497319.html

\section{Анотація}

Постановка проблеми. Статтю присвячено комплексному дослідженню категорії футуральності, що інтегрує стилістичний, лексико-граматичний та комунікативний контексти ії вираження на матеріалі франкомовного публіцистичного дискурсу.

Мета статті полягала в аналізі стильових $i$ комунікативних особливостей публіцистичного дискурсу, дослідженні дискурсивних відмінностей між публічистичним та художнім дискурсами, визначенні типів футуральної семантики в публічистичному дискурсу на матеріалі франиузької мови та виявленні їх комунікативного потенціалу.

Методи дослідження. У статті застосовано системний підхід до дослідження категорії футуральності: методика інтерпретаційного аналізу для виокремлення модусних компонентів та окремих модальних значень категорії футуральності, метод семантичної генералізації для дослідження вживання часових форм категорії футуральності, операиії дискурс-аналізу для виявлення глибинної структури зі значенням майбутності, контекстуальний $і$ функціонально-стилістичний аналізи для виявлення семантики категорії футуральності в окремих мікроконтекстах.

Основні результати дослідження. В основу комунікативно-прагматичного аналізу публічистичного дискурсу, щчо реалізують категорію футуральності, покладено поняття стратегій $і$ тактик мовленнєвого спілкування, загального контексту продукування висловлювання та комунікативної мети мовця, що зреалізовано вмежах окремого мовленнєвого акту. Публіцистичний дискурс інтерпретовано як окремий тип дискурсу корелят публіцистичного стилю. Реалізація комунікативно-прагматичного ефекту в публічистичному типі дискурсу відбувається за рахунок поєднання семантикостилістичного та контекстологічного аналізу висловлювання. Аналіз фактичного матеріалу засвідчив, щео вагому частину частотності вживання категорї футуральності складає прогностична публічистика.

Висновки $\boldsymbol{i}$ перспективи. Виявлено, що публіцистичний дискурс вписується в екзистенційну дискурсивну базову модель. Його сутність полягає в семіотизаиії майбутньої дійсності у віддаленій чи близькій перспективі. Зіставлення вживання граматичних часів публіцистичних та художніх текстів показало відмінність у їхній темпоральній структурі - публіцистичному стилю, на відміну від художнього притаманне збереження повторюваності часового періоду. Публічистичний стиль, як $і$ художній, характеризовано наявністю футуральних контекстів, що містять інтегративні комбінаиіі дієслів руху, семантики самих дієслів, що передають різні види аспектуальних ситуацій $i$ граматичних засобів. У публіцистичному дискурсу французької мови наявні засоби всіх чотирьох способів французької мови, що здатні зреалізувати дві основні форми семантики футуральності - “майбутнє прогноз" та "майбутнє волітивне”. Перспективи подальших досліджень полягають у вивченні вираження категорї футуральності в різних мовленнєвих актах, як-от: емоційно-оцінних, декларативних, директивних, комісивних, репрезентативних, зокрема побажань, дозволів, порад, натяків. Крім того, перспективним $\epsilon$ дослідження категорії футуральності в різних типах дискурсу, зокрема в езотеричному, кулінарному, рекламному, інтенсіональному.

Ключові слова: категорія футуральності, публіцистичний дискурс, семантика футуральності, прогностична функиія, модальність. 


\section{Ukrainian sense. 2020. ISSN 2313-4437}

\section{Abstract}

Background. The article under consideration focuses on the comprehensive research of $C F$, integrating stylistic, lexico-grammatical and communicative contexts of its realization in publicistic discourse of the French language.

The purpose of the study is to investigate the stylistic and communicative peculiarities of the publicistic type of discourse, research the discourse differences between publicistic and literary types of discourse, define the types of futural semantics in publicistic type of discourse in the French language and specify their communicative potential.

Methods of the research. The article under discussion applies comprehensive approach to $C F$ research: interpretation procedure to differentiate modus components and separate modal meanings of $C F$, method of semantic generalization to study the CF tense forms usage, the discourse analysis operations to discover the remote structure with futural meaning, contextual and functional-stylistic analyses to discover $C F$ semantics in separate microcontexts.

Results of the investigation. The notions of strategy and tactics of language communication, overall context of utterance and speaker's communicative aim producing, realized within a single communicative act, are the foundation of the communicative-pragmatic analysis of the types of discourse, implementing CF. Publicistic discourse is regarded as a certain type of discourse, as a correlate of publicistic style. The communicative-pragmatic effect realization in a certain type of discourse may involve the combination of semantic-stylistic and contextological analysis of the utterance. The analysis of the factual material proves that predictive publicism makes a significant part of $C F$ rate of usage.

Discussion. It has been found out that publicistic discourse feeds into existential discourse basic model. Its essence is in semiotization of the future reality in the long term or near-term perspective. The comparison of the tenses usage in publicistic and literary texts has demonstrated the difference in their temporal structure - publicistic style, as opposed to literary style, is characteristic of preservation of frequency of the timeframe. Publicistic style, as well as literary style, contains futural contexts, which include integrative combinations of the verbs of movement, semantics of verbs, conveying different types of aspectual situations and grammar means. Publicistic type of discourse of the French language contains all four moods of French, able to realize two major forms of futural semantics - "future prediction" and "volitive future". Prospects of the future investigations lie in the study of $C F$ expression in different types of language acts such as: emotional-evaluative, declarative, directive, commissive, representative, in particular, wishes, permissions, demands, hints. Moreover, it seems highly potential to research $C F$ in different types of discourse, namely, in esoteric, culinary, advertese, intensional, etc.

Keywords: category of futurality, publicistic discourse, semantics of futurality, prognostic function, modality. 